\title{
Pseudouridines in and near the branch site recognition region of U2 snRNA are required for snRNP biogenesis and pre-mRNA splicing in Xenopus oocytes
}

\author{
XINLIANG ZHAO and YI-TAO YU \\ Department of Biochemistry and Biophysics, University of Rochester Medical Center, Rochester, New York 14642, USA
}

\begin{abstract}
Virtually all uridines in the branch site recognition region (BSRR) of vertebrate U2 are converted into pseudouridines after initial transcription. Here, we report a functional analysis of these modified nucleotides using the Xenopus oocyte reconstitution system. Using site-specific ${ }^{32}$ P-labeling and TLC, we show that U2 pseudouridylation occurs much faster in the BSRR than in the 5 '-terminal region. To functionally dissect the pseudouridines in the BSRR, we replaced each uridine with 5-fluorouridine (unmodifiable nucleotide) using site-specific RNase $\mathrm{H}$ cleavage directed by 2 '- $O$-methyl-RNA-DNA chimeras followed by three-piece ligation. Whereas in vitro transcribed U2 containing no 5-fluorouridines rescued splicing in U2-depleted oocytes, no rescue was observed with U2 RNA containing 5-fluorouridines introduced into the BSRR. Additionally, U2 RNA containing 5 -fluorouridines in the BSRR specifically inhibited pseudouridylation in the BSRR of in vitro transcribed U2 injected at a later time, although pseudouridylation in the $5^{\prime}$-end region was not affected. Our reconstitution results indicated that prior injection into U2-depleted oocytes with U2 RNA containing 5-fluorouridines in the BSRR almost completely abrogated the ability of in vitro transcribed $U 2$ to rescue splicing, whereas full rescue was obtained with either cellular U2 or U2 containing pseudouridines in the BSRR. Further analyses using glycerol-gradient and native gel electrophoresis indicated that U2 RNAs lacking the BSRR pseudouridines do not participate in the assembly of the functionally active 17S U2 snRNP and the spliceosome. We conclude that the BSRR pseudouridines of vertebrate $U 2$ are required for complete snRNP assembly and pre-mRNA splicing in Xenopus oocytes.
\end{abstract}

Keywords: U2 snRNA/snRNP; branch site recognition region (BSRR); U2-U6 helix III; pseudouridine ( $\Psi$ ); 5-fluorouridine; pre-mRNA splicing

\section{INTRODUCTION}

The removal of introns from pre-mRNAs (mRNA splicing) is catalyzed by the spliceosome, a multicomponent complex containing many proteins and five small nuclear (sn) RNAs (U1, U2, U4, U5, and U6; for reviews, see Staley and Guthrie 1998; Burge et al. 1999; Yu et al. 1999; Nilsen 2002; Jurica and Moore 2003). The function of these five snRNAs in pre-mRNA splicing has been studied intensively, and it is well documented that extensive snRNA/pre-mRNA interactions are required for pre-mRNA splicing in the newly assembled spliceosome. For instance, the U1 $5^{\prime}$ invariant sequence base pairs with the $5^{\prime}$-splice site of the pre-mRNA,

Reprint requests to: Yi-Tao Yu, Department of Biochemistry and Biophysics, University of Rochester Medical Center, 601 Elmwood Avenue, Rochester, NY 14642, USA; e-mail: yitao_yu@urmc.rochester.edu; fax: (585) 275-6007.

Article and publication are at http://www.rnajournal.org/cgi/doi/ 10.1261/rna.5159504. and the highly conserved U2 branch site recognition sequence interacts with the branch site of the pre-mRNA. In addition to these Watson-Crick base-pairing interactions, the evolutionarily invariant sequence in the first loop of U5 forms noncanonical base-pairing interactions with both the $5^{\prime}$ - and $3^{\prime}$-splice sites. On the other hand, upon entering the spliceosome, U4 and U6 are extensively base-paired with one another, and the sequences involved in the interactions are highly conserved as well. Before the first step of splicing, the RNA-RNA interactions within the spliceosome undergo dynamic rearrangement. Specifically, U6 dissociates from $\mathrm{U} 4$, displaces $\mathrm{U} 1$ by interacting with the $5^{\prime}$-splice site of the pre-mRNA, and makes new duplexes with U2 snRNA (U2U6 helices I, II, and III). After the first step of splicing, additional conformational changes occur that lead to the second splicing step that generates mature mRNA (Yu et al. 1999).

All five spliceosomal snRNAs are posttranscriptionally modified by pseudouridylation and 2'-O-methylation (for 
reviews, see Reddy and Busch 1988; Massenet et al. 1998). Importantly, the modified nucleotides are mostly concentrated in regions involved in spliceosomal RNA-RNA interactions as described above, suggesting a functional role in pre-mRNA splicing. U2 snRNA is the most extensively modified ( $>10 \%$ of its nucleotides) among all spliceosomal snRNAs. In the single-stranded branch site recognition region (BSRR), including the branch site recognition sequence and the immediate downstream sequence involved in base-pairing interactions with U6 (U2-U6 helix III; Sun and Manley 1995), virtually all uridines are converted to pseudouridines (Fig. 1A). Importantly, this region, which is close to the $5^{\prime}$-end, may also contribute to the binding of several loosely associated U2 proteins (including SF3b) during snRNP biogenesis (Behrens et al. 1993; Kramer et al. 1999). It is known that the association of the loosely associated proteins as well as the tightly associated proteins (including the Sm core proteins) with U2 snRNA is required for the formation of the functionally active 17S U2 snRNP (Behrens et al. 1993; Kramer et al. 1999).

Recent studies on the mechanism of spliceosomal snRNA modification have yielded a general understanding of this process. In vertebrates, U2 modification is catalyzed by small nucleolar (sno) or small Cajal (sca) body-specific RNPs in which the RNA component of the complex serves as a guide for site-specific modification (Huttenhofer et al. 2001; Darzacq et al. 2002; Zhao et al. 2002; Jady et al. 2003). In contrast, Saccharomyces cerevisiae U2 snRNA pseudouridylation is catalyzed by an RNA-independent mechanism (Massenet et al. 1999; Ma et al. 2003).

Although it has been known for decades that all spliceosomal snRNAs contain posttranscriptional modifications, the detailed functional role of these modified nucleotides in pre-mRNA splicing remains largely unknown. Recent NMR studies using a duplex containing the BSRR and its complementary sequence showed that the pseudouridine in the U2 BSRR that base pairs with the nucleotide next to the branch point adenosine in its complementary sequence favors a conformation whereby the branch point adenosine is bulged out (Newby and Greenbaum 2001, 2002). Also, we previously developed a reconstitution strategy for studying the function of U2 modifications in pre-mRNA splicing in Xenopus oocytes (Yu et al. 1998). Briefly, the strategy involves injecting antisense U2 DNA oligonucleotides into oocytes to specifically target the degradation of endogenous U2 snRNA by endogenous RNase $\mathrm{H}$ activity. By the time U2 is depleted, the DNA oligonucleotide is degraded by endogenous DNase activity. Next, we inject chimeric U2 snRNAs that contain naturally modified nucleotides within the region of interest (the remainder of the molecule contains no modifications). After a $3.5-\mathrm{h}$ reconstitution, uniformly ${ }^{32} \mathrm{P}$ labeled standard adenovirus splicing substrate is injected, and pre-mRNA splicing is assessed. Using this system, we demonstrated that modifications within the $5^{\prime}$-most $27 \mathrm{nt}$ of $\mathrm{U} 2$ are required for both snRNP biogenesis and pre-
mRNA splicing (Yu et al. 1998). Surprisingly, however, under these conditions none of the pseudouridines in the U2 BSRR (nucleotides 33-46) were identified as functionally significant.

Given that pseudouridylation within the BSRR is extensive and highly conserved, it is critical to demonstrate experimentally whether the pseudouridines in this region play an important role in pre-mRNA splicing. Here, we specifically analyzed the modified nucleotides within the U2 BSRR and found that the pseudouridines in this region are required for functional U2 snRNP assembly and pre-mRNA splicing.

\section{RESULTS}

\section{U2 modification occurs much faster in the BSRR than in the $5^{\prime}$-end region}

Although it is possible that pseudouridylation in the U2 BSRR is not important for splicing, it is equally possible that pseudouridylation occurs so rapidly in this region that it is already completed before the splicing assay is performed (3.5 $\mathrm{h}$ after reconstitution). To test this possibility, we introduced $\left[\alpha-{ }^{32} \mathrm{P}\right]$ UTP into either the BSRR (nucleotides 3046, U2-BP- ${ }^{32} \mathrm{pU}$, Fig. 1B) or the $5^{\prime}$-region (nucleotides $1-29, \mathrm{U} 2-5^{\prime}-{ }^{32} \mathrm{pU}$, Fig. 1B) and compared the rate of pseudouridylation in these two regions. These radiolabeled U2 RNAs were injected into separate oocytes. After incubation for various times, total nuclear RNA was isolated, digested with nuclease $\mathrm{P} 1$, and the mononucleotides ${ }^{32} \mathrm{pU}$ and ${ }^{32} \mathrm{p} \Psi$ were separated by thin layer chromatography (TLC) and quantified.

At $1 \mathrm{~h}$ postinjection, $\sim 40 \%-50 \%$ pseudouridylation was achieved in the BSRR (Fig. 2, lane 2). In contrast, no pseudouridylation was detected in the $5^{\prime}$-region by this time point (Fig. 2, lane 6). After a 3.5-h incubation (used in our previous study; Yu et al. 1998), 60\%-70\% pseudouridylation was achieved in the BSRR (Fig. 2, lane 3), whereas only $\sim 5 \%$ pseudouridylation was completed in the $5^{\prime}$-region (lane 7). Nearly 90\%-100\% pseudouridylation was achieved in both regions following an overnight incubation (Fig. 2, lanes 4,8$)$. We conclude that U2 pseudouridylation occurs much more rapidly in the BSRR than in the $5^{\prime}$-end region. This conclusion may help explain why we did not detect any important pseudouridines in the BSRR in our previous study (Yu et al. 1998).

\section{U2 RNA containing 5-fluorouridines in the BSRR fails to reconstitute $\mathrm{U} 2$ function in splicing}

To determine whether the pseudouridines in the BSRR are important for splicing, it was apparent that U2 pseudouridylation in this region would need to be slowed or blocked. We introduced the unmodifiable nucleotide 5-fluorouridine (uridine analog) specifically into the BSRR 
A

U2 SnRNA


B
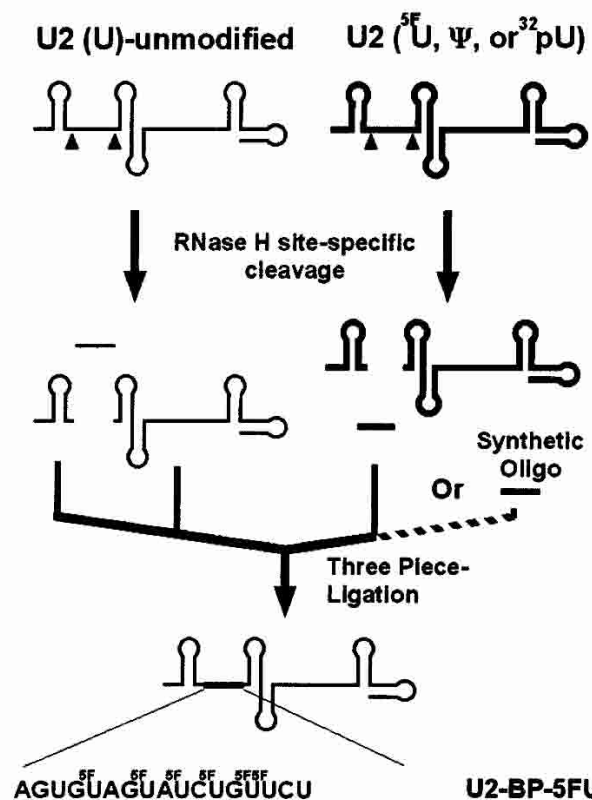

AGUG์บAG์บA้

U2-BP-5FU

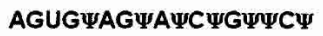

U2-BP- $\Psi$

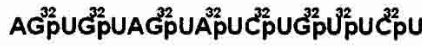

$\mathrm{U} 2-\mathrm{BP}={ }^{32} \mathrm{pU}$



FIGURE 1. (A) The primary sequence (including the modified nucleotides) and the secondary structure of Xenopus U2 snRNA. There are a total of 13 pseudouridines and $102^{\prime}$-O-methylated residues. The Sm-binding site is indicated by a hatched gray box. The underlined nucleotides are involved in base-pairing interactions with the branch site of pre-mRNA. Sequences in dark gray, medium gray, and light gray are involved in base-pairing interactions with U6 snRNA in the spliceosome, known as U2-U6 helices I, II, and III, respectively. (B) The strategy for constructing various $\mathrm{U} 2$ snRNAs. In vitro transcribed $\mathrm{U} 2$ snRNAs containing uridines (U2 [U]-unmodified) or uridine analogs (U2 [ ${ }^{5 \mathrm{~F}} \mathrm{U}, \Psi$, or $\left.{ }^{32} \mathrm{pU}\right]$ in which the uridines are fully substituted with ${ }^{5 \mathrm{~F}} \mathrm{U}, \Psi$, or ${ }^{32} \mathrm{pU}$ ) were subjected to site-specific RNase $\mathrm{H}$ cleavage directed by $2^{\prime}$-O-methyl RNA-DNA chimeras. Three fragments were generated, mixed or matched, and ligated together with T4 DNA ligase in the presence of a bridging DNA oligonucleotide (see Materials and Methods). U2-BP-5FU containing 5-fluorouridines in the BSRR was created by ligating together the unmodified $5^{\prime}$ fragment (nucleotides 1-29), the unmodified $3^{\prime}$ fragment (nucleotides 47-191), and the modified synthetic oligonucleotide (AGUG ${ }^{5 \mathrm{~F}} \mathrm{UAG}^{5 \mathrm{~F}} \mathrm{UA}^{5 \mathrm{~F}} \mathrm{UC}^{5 \mathrm{~F}} \mathrm{UG}^{5 \mathrm{~F}} \mathrm{U}^{5 \mathrm{~F}} \mathrm{UCU}$ corresponding to nucleotides 30-46; purchased from Dharmacon). U2-BP- $\Psi$, which contained pseudouridines in the BSRR, was generated by ligating together the unmodified $5^{\prime}$ fragment (nucleotides 1-33), the unmodified $3^{\prime}$ fragment (nucleotides 47-191), and the modified middle fragment ( $\Psi A G \Psi A \Psi C \Psi G \Psi \Psi C \Psi$, corresponding to nucleotides $34-46$ ). U2-BP- ${ }^{32} \mathrm{pU}$ and $\mathrm{U} 2-5^{\prime}{ }^{32} \mathrm{pU}$, which contain ${ }^{32} \mathrm{P}$-radiolabeled uridines in the BSRR and the $5^{\prime}$ region, respectively, were constructed in the same way except that the branch site recognition fragment or the $5^{\prime}$ fragment was radiolabeled with ${ }^{32} \mathrm{pU}$. 


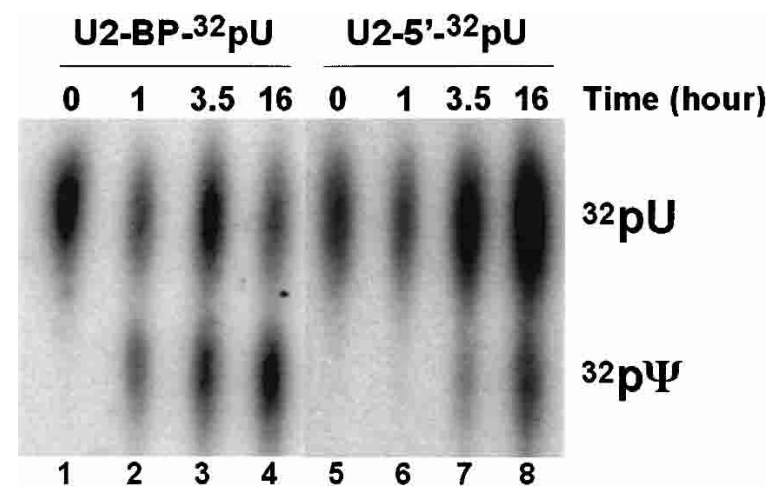

FIGURE 2. The rate of U2 pseudouridylation is faster in the BSRR than in the $5^{\prime}$-end region. U2 RNA containing ${ }^{32} \mathrm{pU}$ in the BSRR (U2-BP- ${ }^{32} \mathrm{pU}$, lanes $1-4$ ) or U2 RNA containing ${ }^{32} \mathrm{pU}$ in the $5^{\prime}$-end region (U2-5' $-{ }^{32} \mathrm{pU}$, lanes $\left.5-8\right)$ was injected into the cytoplasm of Xenopus oocytes. At different time points (indicated above each lane), total nuclear RNA was isolated, treated with nuclease P1, and analyzed by TLC. Lanes 1 and 5 are controls in which uninjected ${ }^{32} \mathrm{pU}$ regionally labeled U2 was directly digested with nuclease P1 and analyzed by TLC in parallel. The positions of uridylate and pseudouridylate migration are indicated.

(see Fig. 1 and Materials and Methods), and the resultant U2 RNA was tested for splicing activity in U2-depleted Xenopus oocytes after an overnight reconstitution (in vitro transcribed U2 is fully modified and functional in splicing after an overnight incubation; Yu et al. 1998). Upon injection into mock-depleted oocytes, pre-mRNA was efficiently spliced (Fig. 3A, lane 2). However, splicing was completely abolished when the oocytes were depleted of endogenous U2 snRNA (Fig. 3A, lane 3). Injection of in vitro transcribed U2 (Fig. 3A, lane 4) or cellular U2 (lane 5) completely restored splicing in oocytes predepleted of U2. In sharp contrast, injection of U2 RNA containing 5-fluorouridines in the BSRR into U2-depleted oocytes failed to rescue premRNA splicing (Fig. 3A, lane 6).

To verify that the amount of various injected $\mathrm{U} 2$ snRNAs accumulated equally in the nuclei, primer-extension analysis of RNAs isolated from the same number of nuclei was performed. As shown in Figure 3B, roughly the same amount of each injected U2 accumulated in the nuclei (lanes 4-6). The level of injected U2 was comparable to that of endogenous U2 in mock-depleted oocytes (Fig. 3B, cf. lanes 4-6 and lane 2), and no U2 was detected in depleted oocytes (lane 3). Because synthetic U2 contains an extra G at the $5^{\prime}$-end (for the purpose of increasing the efficiency of in vitro transcription), the U2 RNA in Figure 3B, lanes 4 and 6, migrated $1 \mathrm{nt}$ slower than that in lanes 2 (endogenous U2) and 5 (cellular U2). As a loading control, U6 snRNA was nearly equally detected in each lane (Fig. 3B, lanes 1-5). These results suggest that the pseudouridines in the BSRR may, indeed, play a role in pre-mRNA splicing. However, it was still possible that the failure of 5-fluoro-U2 RNA to support splicing was due to the 5-fluoro moieties rather than the lack of pseudouridylation.


FIGURE 3. U2 RNA containing 5-fluorouridines in the BSRR fails to reconstitute $\mathrm{U} 2$ function in splicing. (A) In vitro transcribed $\mathrm{U} 2 \mathrm{RNA}$ (lane 4), cellular U2 RNA (lane 5), or U2 RNA containing 5-fluorouridines only in the BSRR (lane 6) was injected into Xenopus oocytes depleted of endogenous U2. After an overnight reconstitution, uniformly ${ }^{32} \mathrm{P}$-labeled adenovirus pre-mRNA substrate was injected, and splicing was analyzed by electrophoresis on an $8 \mathrm{M}$ urea-polyacrylamide gel. In lane 3, U2-depleted oocytes were not supplemented with U2. Lane 2 is a control in which pre-mRNA was directly injected into mock-depleted oocytes. Lane 1 is an uninjected pre-mRNA substrate. Lane $M$ is a size marker of MspI-digested pBR322 DNA. (B) Prior to the injection of ${ }^{32} \mathrm{P}$-labeled adenovirus pre-mRNA substrate, total nuclear RNA was recovered from the same number of oocytes used in lanes 2-6 in $A$, and was extended using $5^{\prime}$-end radiolabeled antisense U2 and U6 oligonucleotides and reverse transcriptase (see Materials and Methods). The oligonucleotides and the primer-extension products are indicated. A rather strong signal migrating just below the U2 band was also observed. We currently do not know the nature of this signal. 


\section{Blocking U2 pseudouridylation in the BSRR inhibits its splicing activity}

To exclude the possibility that 5-fluoro moieties are detrimental to pre-mRNA splicing, we took advantage of the fact that several 5-fluorouridine-containing U2 RNAs tested to date are potent and specific inhibitors of U2 pseudouridylation (Patton et al. 1994; Yu et al. 1998). To check whether U2 RNA containing 5-fluorouridines only in the BSRR has an inhibitory effect on $\mathrm{U} 2$ pseudouridylation in a regionspecific manner, the formation of pseudouridines in two different regions of $\mathrm{U} 2$ was tested. The same amount of in vitro transcribed $\mathrm{U} 2$ or $\mathrm{U} 2$ containing 5 -fluorouridines only

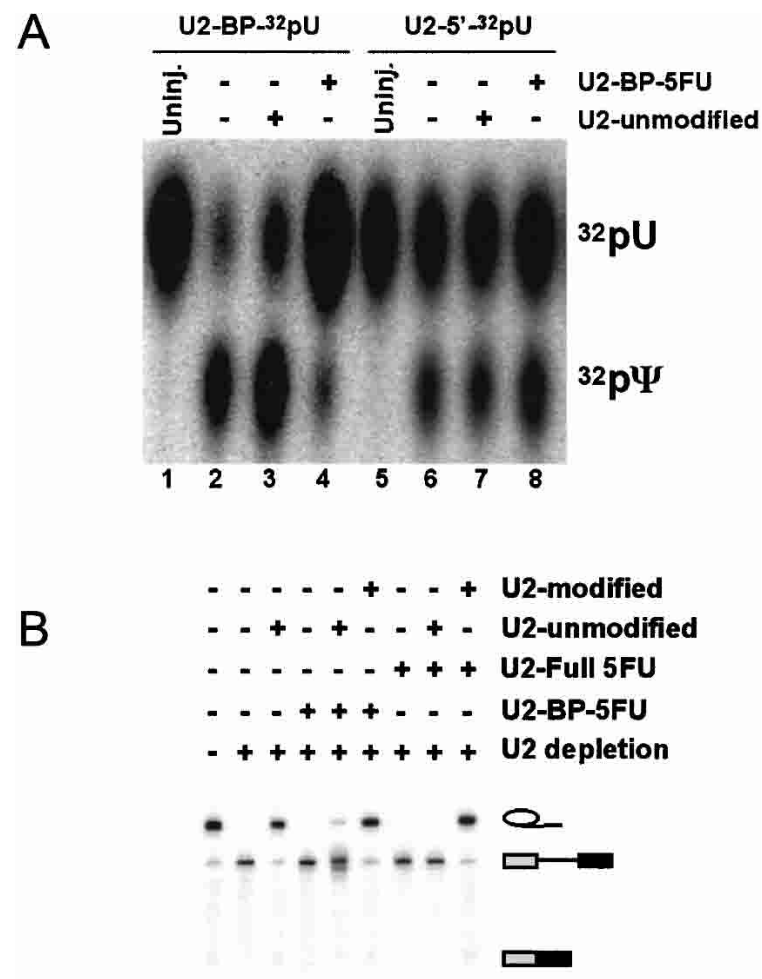

$\begin{array}{lllllllll}1 & 2 & 3 & 4 & 5 & 6 & 7 & 8 & 9\end{array}$

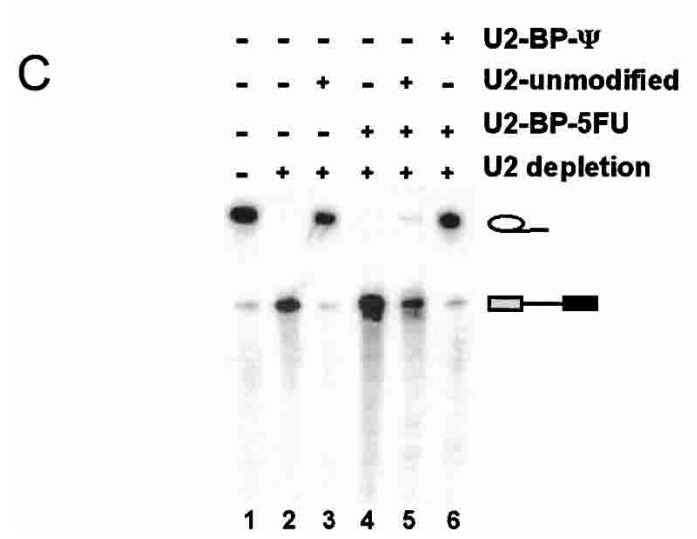

in the BSRR was injected into Xenopus oocytes. Subsequently, synthetic U2 RNA with $\left[\alpha-{ }^{32} \mathrm{P}\right] \mathrm{UTP}$ incorporated only into the $5^{\prime}$-end region (nucleotides 1-29) or into the BSRR (nucleotides 30-46; Fig. 1) was injected, and total nuclear RNA was isolated, digested with P1 nuclease, and analyzed by TLC. Preinjection of in vitro transcribed U2 had no effect on U2 pseudouridylation in either the BSRR (Fig. 4A, lane 3 ) or the $5^{\prime}$-end region (lane 7), as the level of pseudouridylation was comparable to the controls in which no in vitro transcribed U2 was preinjected (Fig. 4A, cf. lane 3 and lane 2, and cf. lane 7 and lane 6). However, preinjection of $\mathrm{U} 2$ containing 5 -fluorouridines in the BSRR almost completely inhibited pseudouridylation in the very same region (Fig. 4A, lane 4) but had no effect on pseudouridylation in the $5^{\prime}$-end region (lane 8), suggesting that this 5-fluorouridine-containing U2, indeed, inhibits U2 pseudouridylation in a region-specific manner.

We next tested whether the inhibition of U2 pseudouridylation in the BSRR consequently affects its function in splicing. U2 RNA containing 5-fluorouridines in the BSRR, or U2 RNA fully substituted with 5-fluorouridines, was injected into U2-depleted oocytes. Subsequently, in vitro transcribed U2 or cellular U2 was injected, and splicing activity was assessed. Subsequent injection of in vitro transcribed U2 completely failed to rescue splicing when fully substituted 5-fluorouridine U2 was preinjected (Fig. 4B, lane 8); only a trace of spliced lariat intron was detected when U2 RNA containing 5-fluorouridines only in the BSRR was present (lane 5), and this level of activity was not comparable to that measured in the absence of the 5-fluorouridine-containing U2 (lane 3). In contrast, the in-

FIGURE 4. Blockage of U2 pseudouridylation in the BSRR inhibits its splicing activity. (A) In vitro transcribed U2 RNA (lanes 3 and 7 , U2-unmodified) or U2 RNA containing 5-fluorouridines in the BSRR (lanes 4 and 8, U2-BP-5FU) was injected into Xenopus oocytes. Subsequently, U2 RNA containing ${ }^{32} \mathrm{P}$-uridines in the BSRR (lanes $1-4$, $\mathrm{U} 2-\mathrm{BP}-{ }^{32} \mathrm{pU}$ ) or in the $5^{\prime}$-end region (lanes $5-8, \mathrm{U} 2-5^{\prime}-{ }^{32} \mathrm{pU}$ ) was injected into the oocytes. Total nuclear RNA was recovered, digested with nuclease P1, and analyzed by TLC. Lanes 2 and 6 are controls in which no in vitro transcribed U2 (U2-unmodified) or 5-fluorouridine-containing $\mathrm{U} 2$ (U2-BP-5FU) was preinjected. Lanes 1 and 5 contain U2 that was labeled region-specifically prior to injection. The positions of ${ }^{32} \mathrm{P}$-radiolabeled uridylate and pseudouridylate are indicated. (B) U2-depleted oocytes (lanes 2-9) were injected with U2 RNA containing 5-fluorouridines in the BSRR (lanes 4-6, U2-BP-5FU) or U2 fully substituted with 5-fluorouridine (lanes 7-9, U2-Full 5FU). Subsequently, in vitro transcribed U2 (lanes 5 and 8 , U2-unmodified), cellular U2 (lanes 6 and 9, U2-modified), or water (lanes 4 and 7) was injected. After an overnight reconstitution, ${ }^{32} \mathrm{P}$-radiolabeled premRNA $\left({ }^{32} \mathrm{P}-\mathrm{Ad}\right)$ was injected, and splicing was assessed on a denaturing gel. Lane 1 is a control in which $\mathrm{U} 2$ was not depleted, and no RNA was supplemented. In lane 2, oocytes were depleted of U2, but not supplemented with any RNA. In lane 3, oocytes were depleted of $\mathrm{U} 2$, and subsequently supplemented with in vitro transcribed $\mathrm{U} 2$. The positions of pre-mRNA, spliced lariat intron, and mRNA are indicated. $(C)$ Experiments were performed exactly as in lanes 1-6 in $B$ except that U2-depleted oocytes in lane 6 were supplemented with U2 RNA in which only the uridines in the BSRR were substituted with pseudouridines (U2-BP- $\Psi$ ). 
jection of cellular $\mathrm{U} 2$ fully restored splicing in the presence of either fully substituted 5-fluorouridine U2 (Fig. 4B, lane 9) or U2 containing 5-fluorouridines only in the BSRR (lane 6).

To confirm our observations, a chimeric U2 RNA was constructed in which pseudouridines were specifically introduced into the BSRR (see Fig. 1 and Materials and Methods). The ability of this RNA to restore splicing in the presence of the pseudouridylation inhibitor (U2 RNA containing 5-fluorouridines only in the BSRR) was tested. U2 RNA containing pseudouridines in the BSRR was sufficient to fully rescue splicing (Fig. 4C, lane 6), as was cellular U2 (lane 6). Again, synthetic U2 containing no modifications failed to restore splicing in the presence of the U2 pseudouridylation inhibitor (Fig. 4C, lane 5). As expected, in the absence of this inhibitor, unmodified synthetic U2 RNA fully restored splicing (Fig. 4C, lane 3). Taken together, we conclude that blockage of $\mathrm{U} 2$ pseudouridylation in the BSRR abolishes splicing activity, thus demonstrating that the pseudouridines in the BSRR are required for pre-mRNA splicing.

\section{U2 RNA lacking pseudouridines in the BSRR is unable to participate in spliceosome assembly}

To further understand the role of the BSRR pseudouridines in pre-mRNA splicing, native gel analysis was performed to test whether the blockage of U2 pseudouridylation within the BSRR has any effect on spliceosome assembly. In mockdepleted oocytes, the splicing complexes $\mathrm{A}, \mathrm{B}$, and $\mathrm{C}$ were efficiently assembled (Fig. 5, lane 1). When endogenous U2 was depleted, no splicing complexes were detected (Fig. 5, lane 2). Injection of in vitro transcribed $\mathrm{U} 2$ into depleted oocytes restored splicing complex formation (Fig. 5, lane 3). In contrast, injection of U2 RNA containing 5-fluorouridines in the BSRR failed to reconstitute any of the splicing complexes in U2-depleted oocytes (Fig. 5, lane 4). Importantly, in the presence of U2 RNA containing 5-fluorouridines in the BSRR, in vitro transcribed U2 was no longer able to reconstitute splicing complex formation (Fig. 5, lane 5), whereas synthetic U2 containing pseudouridines only in the BSRR fully restored complex formation (lane 6). These results suggest that the pseudouridines in the BSRR contribute to spliceosome assembly or to U2 snRNP biogenesis prior to spliceosome assembly.

\section{Pseudouridines in the BSRR of U2 are essential for complete snRNP assembly}

To test whether U2 snRNP biogenesis is affected by U2 pseudouridylation in the BSRR, we carried out anti-Sm immunoprecipitation analysis. U2-depleted oocytes were first injected with U2 containing 5-fluorouridines only in the BSRR, and then with radiolabeled in vitro transcribed $\mathrm{U} 2$ or



FIGURE 5. U2 RNA lacking pseudouridines in the BSRR is unable to participate in spliceosome assembly. Reconstitution was carried out as in Figure 4C. However, after the injection of radiolabeled pre-mRNA, a shorter incubation time was allowed (10 min as opposed to $1.5 \mathrm{~h}$ ). Oocyte nuclei were subsequently isolated and broken, and splicing complexes were analyzed on a native $4 \%$ polyacrylamide gel. The samples are identical to lanes $1-6$ in Figure 4C. The positions of complexes H, A, B, and C (see Konarska 1990 regarding the nature of these complexes) are indicated.

U2 containing pseudouridines in the BSRR. After an overnight incubation, oocyte nuclear extracts were prepared, and anti-Sm immunoprecipitation was performed. We found that both the in vitro transcribed U2 and U2 containing pseudouridines in the BSRR were precipitated efficiently (data not shown), suggesting that U2 snRNA with or without pseudouridines in the BSRR participated in the assembly of Sm snRNP (12S snRNP), which contains tightly associated U2 proteins (including the Sm core proteins; Behrens et al. 1993; Yu et al. 1998).

To assess whether loosely associated U2 proteins were also bound, we then used a glycerol-gradient sedimentation assay under lower salt conditions $(100 \mathrm{mM}$, as opposed to $150 \mathrm{mM}$ for anti-Sm immunoprecipitation). According to the previous reports (Behrens et al. 1993; Yu et al. 1998; Kramer et al. 1999), the use of this mild assay should allow the detection of a complete 17S U2 snRNP, thus permitting the assessment of the association of loosely associated U2 proteins. Here, the same oocyte nuclear extracts used for anti-Sm precipitation were directly loaded onto a glycerol gradient. After centrifugation and fractionation, RNA was recovered and analyzed on a denaturing gel. As expected, U2 containing pseudouridines in the BSRR was concentrated at about $17 \mathrm{~S}$ (Fig. 6, bottom panel, fractions 12-14) as well as $12 \mathrm{~S}$ (Fig. 6, bottom panel, fractions 17-19). In 

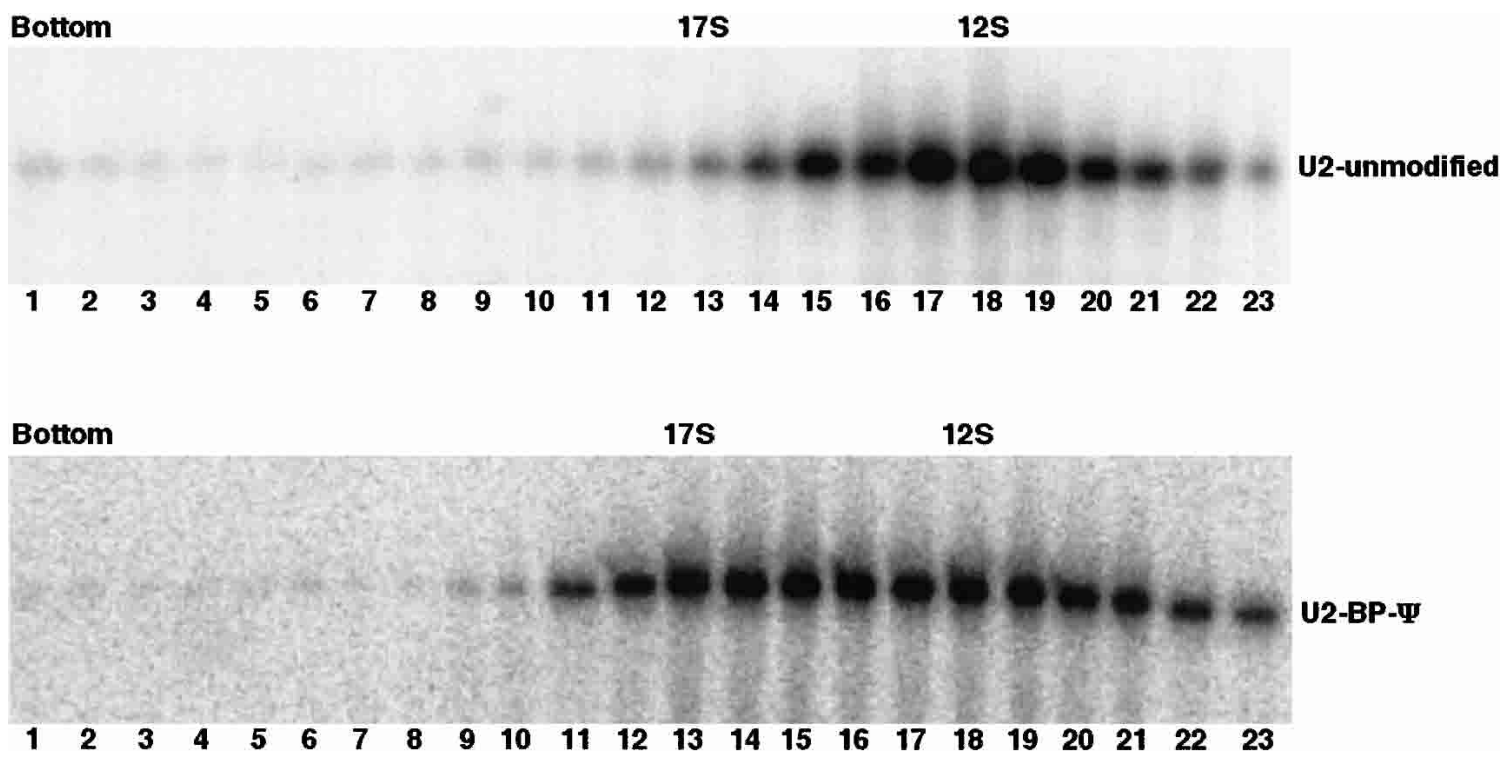

FIGURE 6. Pseudouridines in the BSRR of U2 are crucial for the formation of functionally active U2 snRNP. First, U2 containing 5-fluorouridines in the BSRR was injected into U2-depleted oocytes. After an overnight incubation, the oocytes were then injected with radiolabeled in vitro transcribed U2 (U2-unmodified, top panel) or U2 containing pseudouridines in the BSRR (U2-BP- $\Psi$, bottom panel). Then, $16 \mathrm{~h}$ later, the nuclei were isolated, broken, and loaded onto $20 \%-30 \%$ glycerol gradients $(100 \mathrm{mM} \mathrm{KCl})$. After centrifugation, the 23 fractions $(\sim 500 \mu \mathrm{L}$ each) were collected. RNAs were recovered from each fraction and were resolved on $6 \%$ denaturing polyacrylamide gels. The positions of $17 \mathrm{~S}$ and $12 \mathrm{~S}$ particles are indicated.

contrast, the in vitro transcribed $\mathrm{U} 2$ peaked sharply at $12 \mathrm{~S}$ (Fig. 6, top panel, fractions 17-19); only a close-to-background level of U2 was detected at 17S (Fig. 6, top panel, fractions 12-14). These results indicate that U2 RNA lacking pseudouridines in the BSRR failed to bind to loosely associated $\mathrm{U} 2$ proteins. We conclude that the pseudouridines in the BSRR of $\mathrm{U} 2$ are crucial for complete snRNP assembly.

\section{DISCUSSION}

Using the Xenopus oocyte reconstitution system, we demonstrated that the pseudouridines in the BSRR of U2 are crucial for the assembly of a complete U2 snRNP, which, in turn, are required for spliceosome assembly and pre-mRNA splicing. Specific blockage of pseudouridylation in the BSRR essentially abolished the ability of U2 RNA to form the $17 \mathrm{~S}$ snRNP particle. Consequently, spliceosome assembly and pre-mRNA splicing were inhibited. Although it had been suspected that the pseudouridines in the BSRR might be important for splicing, given the high degree and conservation of pseudouridylation in this region (Reddy and Busch 1988; Massenet et al. 1998), our present work provides experimental proof and clarifies a long-standing question of why the modifications in the $5^{\prime}$-end region, excluding the pseudouridines in the BSRR, were the only ones identified as crucial for pre-mRNA splicing (Yu et al. 1998). The answer has its basis in the assay conditions used in the previous study (3.5-h reconstitution) and the varied rate of modification in distinct regions of U2. Our results indicate that modifications in the $5^{\prime}$-end region of U2 occur rather slowly compared with pseudouridylation within the BSRR. Whereas the 3.5-h reconstitution appears to be ideal for observing the relatively slow modifications (Yu et al. 1998), that timeframe fails with respect to the relatively fast modifications because they are already completed before splicing is assayed $3.5 \mathrm{~h}$ later.

\section{Pseudouridines in the BSRR are necessary for the assembly of functional U2 snRNP and the spliceosome}

Our data suggest that U2 snRNAs lacking pseudouridines in the BSRR fail to participate in the assembly of the 17S U2 snRNP particle and the spliceosome. Given that the $5^{\prime}$ region of U2 RNA (including the BSRR) is involved in the assembly of $17 \mathrm{~S}$ snRNP, in which a few loosely associated proteins including splicing factor SF3b are present (Behrens et al. 1993; Kramer et al. 1999), it is not unexpected that any alteration in the BSRR region would preclude stable interactions with the proteins, thereby preventing the formation of complete U2 snRNP and splicing complexes. However, because blocking pseudouridylation does not constitute conventional base change mutations, the question remains as to how the BSRR containing pseudouridines differs from that containing uridines with respect to interactions with the loosely associated proteins. Compared with uridines, pseudouridines have an extra hydrogen donor that may 
contribute to RNA-protein and/or RNA-RNA interactions. It is therefore possible that the BSRR pseudouridines are directly involved in binding of loosely associated proteins. The lack of pseudouridylation in this region may destabilize the U2-protein interaction, thus affecting the formation of complete snRNP. Alternatively, pseudouridylation in the U2 BSRR may lead to local structural changes in the RNA that are recognized by proteins important for the assembly of complete U2 snRNP. In this regard, it has been reported that pseudouridines can indeed trigger local conformational changes (Arnez and Steitz 1994; Newby and Greenbaum 2001, 2002). Our present data can neither confirm nor rule out the two possibilities, and therefore further studies will be necessary to clarify this issue.

\section{Which pseudouridine(s) in the BSRR is critical?}

Although we have demonstrated that the pseudouridines in the BSRR of U2 are essential for snRNP biogenesis and pre-mRNA splicing, a detailed picture as to which pseudouridine(s) in this region (one, a few, or all) contributes to its function remains unclear. In vertebrate cells, all six uridines in this region are converted to pseudouridines after transcription. The first two pseudouridines ( $\Psi 34$ and $\Psi 37)$ are part of the branch site recognition sequence (nucleotides $33-38)$, and the other four $(\Psi 39, \Psi 41, \Psi 43$, and $\Psi 44)$ are within the immediate downstream sequence involved in base-pairing interactions with U6 (U2-U6 helix III; Sun and Manley 1995). Based on published data, $\Psi 34$ appears to be important for maintaining the bulge of the branch point nucleotide (adenosine) for nucleophilic attack during splicing (Newby and Greenbaum 2001, 2002). It was also reported that the change of U34 to $\Psi 34$ greatly enhances the production of X-RNA, a product generated by a splicingrelated branching reaction in a cell- and protein-free system (Valadkhan and Manley 2003). It is, therefore, conceivable that $\Psi 34$ may be a major contributor to U2 function in pre-mRNA splicing. Interestingly, our present data indicate that the pseudouridines in the BSRR are crucial for the assembly of functional U2 snRNP, leading to a possibility that $\Psi 34$ contributes to snRNP biogenesis as well. The other five pseudouridines in the BSRR may also play a role in promoting snRNP and spliceosome assembly, either individually or synergistically. In this regard, a recent report by King et al. (2003) demonstrated that although a single pseudouridine in the peptidyl transferase center in rRNA is important for healthy growth, the simultaneous removal of several snoRNAs responsible for rRNA pseudouridylation in the peptidyl transferase center resulted in a more severe growth defect phenotype. These results suggest that these pseudouridines may contribute to rRNA function in a synergistic manner. Clearly, more detailed studies of the six pseudouridines in the BSRR are necessary to clarify whether their function in U2 is analogous to that of the pseudouridines in rRNA.

\section{MATERIALS AND METHODS}

\section{Construction of various U2 snRNAs}

T7 in vitro transcription was used to generate unmodified U2, or U2 snRNA fully substituted with 5-fluorouridines or pseudouridines. The transcription reaction mixture contained $1.4 \mathrm{mM}$ each of ATP, CTP, UTP, and GpppG; and $0.28 \mathrm{mM}$ GTP (all from New England BioLabs), $40 \mathrm{mM}$ Tris- $\mathrm{HCl}$ ( $\mathrm{pH} 7.5), 6 \mathrm{mM} \mathrm{MgCl}_{2}, 2 \mathrm{mM}$ spermidine, $5 \mathrm{mM}$ dithiothreitol (DTT), $0.1 \mathrm{mM} / \mathrm{mL}$ SmaIlinearized T7-U2 plasmid (containing one extra G at the $5^{\prime}$-end for better transcription, and three $\mathrm{Cs}$ at the $3^{\prime}$-end resulting from SmaI cleavage), and $4 \mathrm{U} / \mu \mathrm{L}$ T7 RNA polymerase. To create U2 RNA fully substituted with 5-fluorouridines or pseudouridines, $1.2 \mathrm{mM}$ UTP was replaced by either $1.2 \mathrm{mM}$ 5-fluorouridine triphosphate (Sierra Bioresearch) or $1.2 \mathrm{mM}$ pseudouridine triphosphate (Sierra Bioresearch), respectively. To create radiolabeled U2, UTP was reduced to $0.12 \mathrm{mM}$, and $\left[\alpha-{ }^{32} \mathrm{P}\right] \mathrm{UTP}(2 \mu \mathrm{Ci} / \mu \mathrm{L}$; DuPont/NEN) was included.

To construct U2 RNA containing 5-fluorouridines only in the BSRR, in vitro transcribed U2 snRNA was subjected to site-specific cleavage by RNase $\mathrm{H}$ in the presence of $2^{\prime}$-O-methyl RNA-DNA chimeras ( $\mathrm{Yu}$ 2000). Two such chimeras were used here: $A_{m} C_{m} U_{m}$ dTdGdAdTC ${ }_{m} U_{m} U_{m} A_{m} G_{m} C_{m} C_{m} A_{m} A_{m} A_{m} A_{m}$ direct-

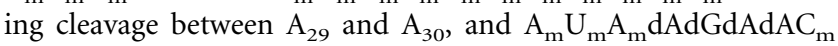
$A_{m} G_{m} A_{m} U_{m} A_{m} C_{m} U_{m} A_{m} C_{m} A_{m}$ for cleavage between $U_{46}$ and $\mathrm{U}_{47}$. Three $\mathrm{U} 2$ fragments were, therefore, generated after RNase $\mathrm{H}$ cleavage: the $5^{\prime}$ fragment (nucleotides 1-29), the branch site recognition fragment (nucleotides 30-46), and the 3' fragment (nucleotides 47-191). The $5^{\prime}$ fragment, the $3^{\prime}$ fragment, and a synthetic 5-fluorouridine-containing oligonucleotide $\left(\mathrm{AGUG}^{5 \mathrm{~F}}\right.$ $\mathrm{UAG}^{5 \mathrm{~F}} \mathrm{UA}^{5 \mathrm{~F}} \mathrm{UC}^{5 \mathrm{~F}} \mathrm{UG}^{5 \mathrm{~F}} \mathrm{U}^{5 \mathrm{~F}} \mathrm{UCU}$; Dharmacon) were aligned using a bridging DNA oligonucleotide complementary to nucleotides 1-67 of U2, and ligated together by T4 DNA ligase (USB), essentially as described (Moore and Sharp 1992; Yu et al. 1998; Yu 1999, 2000). The resultant U2 snRNA contained six 5-fluorouridines at positions $34,37,39,41,43$, and 44 that are otherwise naturally pseudouridylated (see Fig. 1).

To construct a U2 RNA containing pseudouridines only in the BSRR, both in vitro transcribed U2 and U2 fully substituted with pseudouridines were subjected to site-specific cleavage by RNase $\mathrm{H}$ directed by $2^{\prime}-\mathrm{O}$-methyl RNA-DNA chimeras. Two such chimeras $\left(\mathrm{C}_{m} \mathrm{U}_{\mathrm{m}} \mathrm{A}_{\mathrm{m}} \mathrm{dCdAdCdTU} \mathrm{U}_{\mathrm{m}} \mathrm{G}_{\mathrm{m}} \mathrm{A}_{\mathrm{m}} \mathrm{U}_{\mathrm{m}} \mathrm{C}_{\mathrm{m}} \mathrm{U}_{\mathrm{m}} \mathrm{U}_{\mathrm{m}} \mathrm{A}_{\mathrm{m}} \mathrm{G}_{\mathrm{m}} \mathrm{C}_{\mathrm{m}} \mathrm{C}_{\mathrm{m}}\right.$, which directs cleavage between $\mathrm{G} 33$ and $\mathrm{U} 34$, and $\mathrm{A}_{\mathrm{m}} \mathrm{U}_{\mathrm{m}} \mathrm{A}_{\mathrm{m}}$ dAdGdAdAC $\mathrm{m}_{m} \mathrm{~A}_{m} \mathrm{G}_{\mathrm{m}} \mathrm{A}_{\mathrm{m}} \mathrm{U}_{\mathrm{m}} \mathrm{A}_{\mathrm{m}} \mathrm{C}_{\mathrm{m}} \mathrm{U}_{\mathrm{m}} \mathrm{A}_{\mathrm{m}} \mathrm{C}_{\mathrm{m}} \mathrm{A}_{\mathrm{m}}$, which directs cleavage between $\mathrm{U}_{46}$ and $\mathrm{U}_{47}$ ) were used, and three $\mathrm{U} 2$ fragments were generated (the $5^{\prime}$ fragment, nucleotides 1-33; the branch site recognition fragment, nucleotides $34-46$; and the $3^{\prime}$ fragment, nucleotides 47-191). The $5^{\prime}$ fragment and the $3^{\prime}$ fragment derived from in vitro transcribed $\mathrm{U} 2$ and the branch site recognition fragment derived from U2 fully substituted with pseudouridines were aligned using the bridging DNA oligonucleotide and ligated together by T4 DNA ligase (Moore and Sharp 1992; Yu et al. 1998; Yu 1999, 2000). The resultant U2 contained seven pseudouridines ( $\Psi 34, \Psi 37, \Psi 39, \Psi 41, \Psi 43, \Psi 44$, and $\Psi 46$; only $\Psi 46$ is not a natural pseudouridylation site) in the BSRR.

To construct regionally labeled $\mathrm{U} 2$, both unlabeled and $\left[\alpha-{ }^{32} \mathrm{P}\right] \mathrm{UTP}$-uniformly labeled in vitro transcribed U2 RNAs were subjected to site-specific cleavage by RNase $\mathrm{H}$ directed by $2^{\prime}-O$ methyl RNA-DNA chimeras. The chimeras used were: $\mathrm{A}_{\mathrm{m}} \mathrm{C}_{\mathrm{m}} \mathrm{U}_{\mathrm{m}}$ 
dTdGdAdTC $_{m} U_{m} U_{m} A_{m} G_{m} C_{m} C_{m} A_{m} A_{m} A_{m} A_{m}$ directing cleavage between $A_{29}$ and $A_{30}$, and $A_{m} U_{m} A_{m}$ dAdGdAdAC $A_{m} A_{m} A_{m}$ $\mathrm{U}_{\mathrm{m}} \mathrm{A}_{\mathrm{m}} \mathrm{C}_{\mathrm{m}} \mathrm{U}_{\mathrm{m}} \mathrm{A}_{\mathrm{m}} \mathrm{C}_{\mathrm{m}} \mathrm{A}_{\mathrm{m}}$ that directs cleavage between $\mathrm{U}_{46}$ and $\mathrm{U}_{47}$. To create a U2 RNA containing ${ }^{32} \mathrm{P}$-uridines in the $5^{\prime}$ region (1-29), the $5^{\prime}$ fragment (nucleotides 1-29) derived from labeled $\mathrm{U} 2$ as well as the branch site recognition fragment (nucleotides 30-46) and the $3^{\prime}$ fragment (nucleotides 47-191; both derived from the unlabeled U2) were ligated together. To create a U2 containing ${ }^{32} \mathrm{P}$-uridines in the BSRR (30-46), the $5^{\prime}$ fragment (nucleotide 1-29) and the $3^{\prime}$ fragment (47-191), both derived from unlabeled U2, were ligated onto each end of the branch site recognition fragment (nucleotides 30-46) derived from U2 uniformly radiolabeled with $\left[\alpha-{ }^{32} \mathrm{P}\right] \mathrm{UTP}$. The theoretical value of the $\mathrm{U}: \Psi$ ratio in the $5^{\prime}$-end fragment (nucleotides 1-29) was 7:3 (according to human U2 sequence; see Reddy and Busch 1988). Likewise, the ratio of $U: \Psi$ in the BSRR (nucleotides 30-46) was 2:6.

\section{Xenopus oocyte microinjection and reconstitution of pre-mRNA splicing}

Microinjection and reconstitution were performed essentially as described previously (Yu et al. 1998; Zhao et al. 2002). Briefly, 46 $\mathrm{nL}$ of $2 \mathrm{mg} / \mathrm{mL}$ antisense U2 DNA oligonucleotide (complementary to nucleotides 28-42) was injected into the cytoplasm of Xenopus oocytes. After the endogenous U2 was completely degraded by endogenous RNase $\mathrm{H}$ activity $(>4 \mathrm{~h}), 40 \mathrm{~nL}$ of $50 \mathrm{ng} / \mu \mathrm{L}$ rescuing U2 snRNA (in vitro transcribed U2, cellular U2, or U2 containing 5-fluorouridines only in the BSRR) was injected into the cytoplasm of the oocytes. Following an overnight $(\sim 16 \mathrm{~h})$ reconstitution, $9 \mathrm{~nL}$ of $\left[\alpha-{ }^{32} \mathrm{P}\right] \mathrm{UTP}$-radiolabeled adenovirus splicing substrate $(500,000 \mathrm{cpm} / \mu \mathrm{L})$ was directly injected into the nucleus of oocytes. After $1.5 \mathrm{~h}$, nuclei were isolated, treated with proteinase $\mathrm{K}$, and total nuclear RNA was extracted with PCA and then precipitated with ethanol. The recovered RNA was loaded on a $5.5 \%$ polyacrylamide- $8 \mathrm{M}$ urea gel (acryamide:bis $=19: 1$; EM Science). Labeled pre-mRNA and splicing intermediates and products were visualized after autoradiography.

To check the level of U2 snRNA accumulated in the nuclei, primer extension analysis was carried out according to $\mathrm{Yu}$ et al. (1998). Total nuclear RNA recovered from six oocytes that had not been injected with the radiolabeled splicing substrate was used as template RNA. Two $5^{\prime}$-end ${ }^{32} \mathrm{P}$-radiolabeled DNA oligonucleotides (U2-b, complementary to nucleotides 27-49 of U2, and U6b, complementary to nucleotides 78-95 of U6) were used as reverse transcription primers.

To study whether the inhibitory effect of 5-fluorouridine-containing U2 on U2 pseudouridylation influences functional reconstitution of U2 and splicing, $40 \mathrm{~nL}$ of $50 \mathrm{ng} / \mu \mathrm{L} 5$-fluorouridinecontaining U2 was injected into the cytoplasm of U2-depleted oocytes. After $16 \mathrm{~h}, 40 \mathrm{~nL}$ of $50 \mathrm{ng} / \mu \mathrm{L}$ rescuing $\mathrm{U} 2$ (in vitro transcribed U2, cellular U2, or U2 containing pseudouridines only in the BSRR) was injected into the cytoplasm of the oocytes. After another 16-h incubation, $9 \mathrm{~nL}$ of $\left[\alpha-{ }^{32} \mathrm{P}\right] \mathrm{UTP}$-radiolabeled adenovirus splicing substrate $(500,000 \mathrm{cpm} / \mu \mathrm{L})$ was injected into the oocyte nuclei, and splicing was analyzed as above.

\section{Pseudouridylation assay}

To assess the pseudouridylation rate in different regions of $\mathrm{U} 2, \mathrm{U} 2$ RNA containing ${ }^{32} \mathrm{P}$-uridines either in the $5^{\prime}$ region only (nucleo- tides 1-29) or in the BSRR only (nucleotides 30-46) were separately injected into the cytoplasm of Xenopus oocytes. At different time points after injection, nuclei were isolated and total nuclear RNA was recovered by PCA extraction and ethanol precipitation. The recovered RNA was then digested with nuclease P1 (final 200 $\mu \mathrm{g} / \mathrm{mL}$ in $3 \mu \mathrm{L}$ of sodium acetate at $\mathrm{pH} 5.2$ ) for $1 \mathrm{~h}$ at $37^{\circ} \mathrm{C}$. The digested samples were dotted on TLC PEI plates (EM Science) and chromatographed in the $\mathrm{HCl}-\mathrm{H}_{2} \mathrm{O}-$ isopropanol $(15: 15: 70, \mathrm{v} / \mathrm{v} / \mathrm{v})$ buffer for $\sim 6-7$ h. ${ }^{32} \mathrm{pU}$ and ${ }^{32} \mathrm{p} \Psi$ were separated and visualized by autoradiography. The ratio of ${ }^{32} \mathrm{pU} /{ }^{32} \mathrm{p} \Psi$ was determined using a PhosphorImager (Molecular Dynamics).

To check the specific inhibitory effect of 5-fluorouridine-containing U2 on U2 pseudouridylation, $40 \mathrm{~nL}$ of $50 \mathrm{ng} / \mu \mathrm{L} \mathrm{U} 2 \mathrm{RNA}$ containing 5-fluorouridines only in the BSRR (or in vitro transcribed U2 as a control) was injected into the cytoplasm of Xenopus oocytes. After 16 h, U2 RNA containing ${ }^{32} \mathrm{P}$-uridines only in the 5 ' region (nucleotides 1-29) or in the BSRR (nucleotides 3046) was injected into the cytoplasm of Xenopus oocytes. After another 16-h incubation, nuclei were isolated and total RNA was recovered. Pseudouridylation of radiolabeled U2 was analyzed by TLC as above.

\section{Analysis of splicing complexes by native gel electrophoresis}

Spliceosome assembly was analyzed according to previous reports (Konarska 1990; Yu et al. 1998). Briefly, $10 \mathrm{~min}$ after nuclear injection of $9 \mathrm{~nL}$ of radiolabeled adenovirus splicing substrate (500,000 cpm/ $\mu \mathrm{L}$; see above), nuclei were isolated and broken by pipetting up and down several times in $10 \mu \mathrm{L}$ of loading dye containing $9 \mathrm{mM}$ HEPES ( $\mathrm{pH}$ 7.9), $22.5 \mathrm{mM} \mathrm{KCl}, 0.09 \mathrm{mM}$ EDTA, $0.22 \mathrm{mM}$ DTT, and $1 \mathrm{mg} / \mathrm{mL}$ heparin. The samples were then loaded on a $4 \%$ polyacrylamide native gel (acrylamide: bis $=80: 1$ ). The splicing complexes were visualized by autoradiography.

\section{Immunoprecipitation and glycerol-gradient analysis}

Anti-Sm (Y12) immunoprecipitation was carried out essentially as described (Lerner et al. 1981; Yu et al. 1998). Briefly, $40 \mathrm{~nL}$ of 50 $\mathrm{ng} / \mu \mathrm{L}$ U2 RNA containing 5-fluorouridines in the BSRR was injected into the cytoplasm of U2-depleted Xenopus oocytes. Then, 16 h later, uniformly radiolabeled in vitro transcribed U2 or U2 containing pseudouridines in the BSRR was injected into the oocyte cytoplasm (20,000 cpm/oocyte). After an overnight incubation, the oocyte nuclei were isolated and broken by pipetting up and down many times using P10 tips followed by vigorous mixing in the Net-2 buffer $(50 \mathrm{mM}$ Tris- $\mathrm{HCl}$ at $\mathrm{pH} 7.5,150 \mathrm{mM} \mathrm{NaCl}$, $0.05 \% \mathrm{NP}-40$ ). The sample was then clarified by centrifugation at $13,000 \mathrm{~g}$ for $5 \mathrm{~min}$, and the supernatant was mixed with anti-Sm antibodies (Y12) prebound to protein A-Sepharose. The mixture was then nutated for $2 \mathrm{~h}$ at $4^{\circ} \mathrm{C}$. After centrifugation, the beads were washed four times with Net- 2 buffer and digested with proteinase $\mathrm{K}$ at $42^{\circ} \mathrm{C}$ in $\mathrm{G} 50$ buffer $(20 \mathrm{mM}$ Tris- $\mathrm{HCl}$ at $\mathrm{pH} 7.5,300$ $\mathrm{mM}$ sodium acetate, $2 \mathrm{mM}$ EDTA, and $0.3 \%$ SDS). RNAs were recovered by PCA extraction and ethanol precipitation, and resolved on a $6 \%$ denaturing gel, and the radiolabeled U2 RNA was visualized by autoradiography.

For glycerol-gradient analysis, the above broken oocyte nuclei 
were mixed with $200 \mu \mathrm{L}$ of buffer containing $20 \mathrm{mM}$ HEPES ( $\mathrm{pH}$ 7.9), $100 \mathrm{mM} \mathrm{KCl}, 1.5 \mathrm{mM} \mathrm{MgCl}_{2}, 0.2 \mathrm{mM}$ EDTA, $0.5 \mathrm{mM}$ dithioerythritol (DTE), $0.5 \mathrm{mM}$ phenylmethylsulfonyl fluoride (PMSF), and $4 \mathrm{mg} / \mathrm{mL}$ leupeptin (Behrens et al. 1993). The nuclear suspension was then loaded onto a linear 20\%-30\% glycerol gradient $(11 \mathrm{~mL})$ prepared in the same buffer. After centrifugation in an SW40Ti rotor (Beckman) at $29,000 \mathrm{rpm}$ for $16.5 \mathrm{~h}$ at $4^{\circ} \mathrm{C}$, the gradient was fractionated into $23 \sim 0.5-\mathrm{mL}$ fractions from bottom to top. The fractions were treated with proteinase $\mathrm{K}$, extracted with PCA, and precipitated with ethanol. Recovered RNAs were subsequently resolved on a $6 \%$ denaturing gel. The radiolabeled U2 RNAs were visualized by autoradiography.

\section{ACKNOWLEDGMENTS}

We thank members of the Yu laboratory for valuable discussions. This work was supported by grant GM62937 from the National Institutes of Health.

The publication costs of this article were defrayed in part by payment of page charges. This article must therefore be hereby marked "advertisement" in accordance with 18 USC section 1734 solely to indicate this fact.

Received August 19, 2003; accepted January 12, 2004.

\section{REFERENCES}

Arnez, J.G. and Steitz, T.A. 1994. Crystal structure of unmodified tRNA $^{\text {Gln }}$ complexed with glutaminyl-tRNA synthetase and ATP suggests a possible role for pseudo-uridines in stabilization of RNA structure. Biochemistry 33: 7560-7567.

Behrens, S.-E., Tyc, K., Kastner, B., Reichelt, J., and Luhrmann, R. 1993. Small nuclear ribonucleoprotein (RNP) U2 contains numerous additional proteins and has a bipartite RNP structure under splicing conditions. Mol. Cell. Biol. 13: 307-319.

Burge, C.B., Tuschl, T.H., and Sharp, P.A. 1999. Splicing of precursors to mRNAs by the spliceosomes. In The RNA world, 2nd ed. (eds. R.F. Gesteland et al.), pp. 525-560. Cold Spring Harbor Laboratory Press, Cold Spring Harbor, NY.

Darzacq, X., Jady, B.E., Verheggen, C., Kiss, A.M., Bertrand, E., and Kiss, T. 2002. Cajal body-specific small nuclear RNAs: A novel class of $2^{\prime}$-O-methylation and pseudouridylation guide RNAs. EMBO J. 21: 2746-2756.

Huttenhofer, A., Kiefmann, M., Meier-Ewert, S., O’Brien, J., Lehrach, H., Bachellerie, J.P., and Brosius, J. 2001. RNomics: An experimental approach that identifies 201 candidates for novel, small, non-messenger RNAs in mouse. EMBO J. 20: 2943-2953.

Jady, B.E., Darzacq, X., Tucker, K.E., Matera, A.G., Bertrand, E., and Kiss, T. 2003. Modification of Sm small nuclear RNAs occurs in the nucleoplasmic Cajal body following import from the cytoplasm. EMBO J. 22: 1878-1888.

Jurica, M.S. and Moore, M.J. 2003. Pre-mRNA splicing: Awash in a sea of proteins. Mol. Cell 12: 5-14.

King, T.H., Liu, B., McCully, R.R., and Fournier, M.J. 2003. Ribosome structure and activity are altered in cells lacking snoRNPs that form pseudouridines in the peptidyl transferase center. Mol. Cell
11: $425-435$.

Konarska, M.M. 1990. Analysis of splicing complexes and small nuclear ribonucleoprotein particles by native gel electrophoresis. Methods Enzymol. 180: 442-453.

Kramer, A., Gruter, P., Groning, K., and Kastner, B. 1999. Combined biochemical and electron microscopic analyses reveal the architecture of the mammalian U2 snRNP. J. Cell Biol. 145: 1355-1368.

Lerner, E.A., Lerner, M.R., Janeway, C.A., and Steitz, J.A. 1981. Monoclonal antibodies to nucleic acid-containing cellular constituents: Probes for molecular biology and autoimmune disease. Proc. Natl. Acad. Sci. 78: 2737-2741.

Ma, X., Zhao, X., and Yu, Y.-T. 2003. Pseudouridylation $(\Psi)$ of U2 snRNA in S. cerevisiae is catalyzed by an RNA-independent mechanism. EMBO J. 22: 1889-1897.

Massenet, S., Mougin, A., and Branlant, C. 1998. Posttranscriptional modifications in the $\mathrm{U}$ small nuclear RNAs. In The modification and editing of RNA (eds. H. Grosjean and R. Benne), pp. 201-228. ASM Press, Washington, DC.

Massenet, S., Motorin, Y., Lafontaine, D.L., Hurt, E.C., Grosjean, H., and Branlant, C. 1999. Pseudouridine mapping in the Saccharomyces cerevisiae spliceosomal U small nuclear RNAs (snRNAs) reveals that pseudouridine synthase puslp exhibits a dual substrate specificity for U2 snRNA and tRNA. Mol. Cell. Biol. 19: 2142-2154.

Moore, M.J. and Sharp, P.A. 1992. Site-specific modification of premRNA: The 2' hydroxyl groups at the splice sites. Science 256: 992997.

Newby, M.I. and Greenbaum, N.L. 2001. A conserved pseudouridine modification in eukaryotic U2 snRNA induces a change in branchsite architecture. RNA 7: 833-845.

- 2002. Sculpting of the spliceosomal branch site recognition motif by a conserved pseudouridine. Nat. Struct. Biol. 9: 958-965.

Nilsen, T.W. 2002. The spliceosome: No assembly required? Mol. Cell 9: 8-9.

Patton, J.R., Jacobson, M.R., and Pederson, T. 1994. Pseudouridine formation in U2 small nuclear RNA. Proc. Natl. Acad. Sci. 91: 3324-3328.

Reddy, R. and Busch, H. 1988. Small nuclear RNAs: RNA sequences, structure, and modifications. In Structure and function of major and minor small nuclear ribonucleoprotein particles (ed. M.L. Birnstiel), pp. 1-37. Springer-Verlag, Berlin.

Staley, J.P. and Guthrie, C. 1998. Mechanical device of the spliceosome: Motors, clocks, springs, and things. Cell 92: 315-326.

Sun, J.-S. and Manley, J.L. 1995. A novel U2-U6 snRNA structure is necessary for mammalian mRNA splicing. Genes \& Dev. 9: 843-854.

Valadkhan, S. and Manley, J.L. 2003. Characterization of the catalytic activity of U2 and U6 snRNAs. RNA 9: 892-904.

Yu, Y.-T. 1999. Construction of 4-thiouridine site-specifically substituted RNAs for cross-linking studies. Methods 18: 13-21.

Yu, Y.-T. 2000. Site-specific 4-thiouridine incorporation into RNA molecules. Methods Enzymol. 318: 71-88.

Yu, Y.-T., Shu, M.-D., and Steitz, J.A. 1998. Modifications of U2 snRNA are required for snRNP assembly and pre-mRNA splicing. EMBO J. 17: 5783-5795.

Yu, Y.-T., Scharl, E.C., Smith, C.M., and Steitz, J.A. 1999. The growing world of small nuclear ribonucleoproteins. In The RNA world, 2nd ed. (eds. R.F. Gesteland et al.), pp. 487-524. Cold Spring Harbor Laboratory Press, Cold Spring Harbor, NY.

Zhao, X., Li, Z.-H., Terns, R.M., Terns, M.P., and Yu, Y.-T. 2002. An H/ACA guide RNA directs U2 pseudouridylation at two different sites in the branchpoint recognition region in Xenopus oocytes. RNA 8: 1515-1525. 

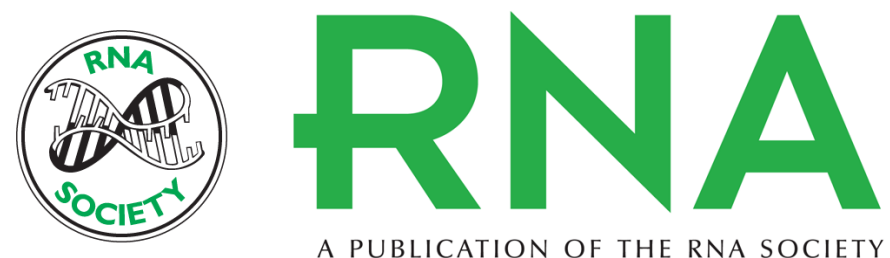

A PUBLICATION OF THE RNA SOCIETY

\title{
Pseudouridines in and near the branch site recognition region of $\mathrm{U} 2$ snRNA are required for snRNP biogenesis and pre-mRNA splicing in Xenopus oocytes
}

\author{
XINLIANG ZHAO and YI-TAO YU
}

RNA 2004 10: 681-690

References This article cites 24 articles, 15 of which can be accessed free at:

http://rnajournal.cshlp.org/content/10/4/681.full.html\#ref-list-1

License

Email Alerting Receive free email alerts when new articles cite this article - sign up in the box at the

Service top right corner of the article or click here.

To subscribe to RNA go to:

http://rnajournal.cshlp.org/subscriptions 